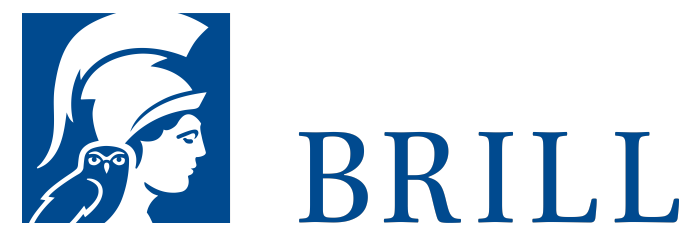

\title{
Neokonservatismus und amerikanische Außenpolitik
}

Ideen, Krieg und Strategie von Ronald Reagan bis George W. Bush

Author: Patrick Keller

Im Streit um die amerikanische Außen- und Anti-Terror-Politik seit dem 11. September 2001 gibt es einen beherrschenden Kampfbegriff: Neokonservatismus. Eine Clique neokonservativer Ideologen, so der Vorwurf, habe den intellektuellen Hintergrund für den neuen amerikanischen Imperialismus und besonders für den Krieg gegen den Irak geschaffen. Wer aber sind diese Neocons, was macht den Kern ihres Denkens aus und wie haben sie auf die Politik der Weltmacht Einfluss genommen? Patrick Keller, gründlicher Kenner der amerikanische Geistesgeschichte und der internationalen Politik, legt die erste in die Tiefe gehende Studie der Neocons vor. Er schildert, wie eine militante Denkschule und ihre führenden Vertreter unter den Präsidenten Ronald Reagan und George W. Bush die amerikanische Strategie prägten - und die USA schließlich mit ihrer einseitigen Politik der Stärke in das Desaster des Irak-Krieges führten, mit dessen Folgen nun nicht nur sie zu ringen haben. In brillanten Portraits der 'Väter' der Neocons wie Irving Kristol und Norman Podhoretz, Henry Jackson und Nathan Glazer zeichnet Keller zunächst die Entstehungsgeschichte des Neokonservatismus seit dem in den 196oer Jahren erfolgten Bruch mit dem Linksliberalismus nach und entfaltet sodann den ideologischen Hintergrund der Außenpolitiken der Reagan- und BushAdministrationen. Diese erste umfassende und ausgewogene Studie...

See More

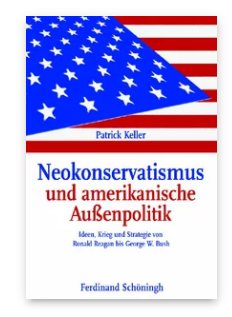

Pages: 344

Seiten

Language:

German

Subjects:

Economics \&

Political Science, Social Sciences

Publisher: Brill |

Schöningh

Hardback

Publication date:

23 Jan 2008

ISBN: $978-3-$

506-76528-4

List price

USD $\$ 54.00$ 
For more information see brill.com

Order information: Order online at brill.com +44330 333 0049 | customerservices@brill.com Submission information: brill.com/authors

Titles published by Brill | Fink, Brill | mentis or Brill | Schöningh: +49(o)715413279216| brill@brocom.de 